\title{
An Extensive Compendium on Good Practices in Secondary Education in Greece
}

\author{
Konstantinos Zacharis ${ }^{1, *}$ \\ ${ }^{1}$ Staffordshire University, UK \\ *Correspondence: Staffordshire University, UK. E-mail: kzaharis@gmail.com
}

Received: February 8, 2017 Accepted: April 7, 2017 Online Published: April 15, 2017

doi:10.5430/wje.v7n2p39 URL: https://doi.org/10.5430/wje.v7n2p39

\begin{abstract}
The establishment of a competitive, meritocratic and engaging culture inside the educational system is one of the crucial elements that will determine not only its survival but also its evolution as a vault of social progress and cultural elevation. Within this frame, mechanisms that can establish new relationships for excellence and innovation inside educational organizations are examined and therefore these can become future gnomons. A correlation of data from a three-year institution award records, provided by the Greek Ministry of Education, is being attempted, in order to mine information about the specific characteristics of the eminent institutions.

The gain of similar practices for the school community is doublefold: at first, it measures accurately enough, on a scientific basis, the impact and progressiveness on the community and secondly it safely sketches its future status by projecting on the most popular and easily implemented features. In the meantime, there is a growing discussion on how these radical changes could be assimilated by the majority of schools, if one imposes them in a top-down policy or if one awaits until they emerge from a cooperative and social responsible action of the school unit level.

A new parameter in the idea of excellence is the newly established pilot-experimental schools, which operate already in a completely novel institutional environment. Among the objectives of the ministry of education is to confide in them a major role, that of "locomotives of excellence", throughout the whole country. The idea of "excellence", though quite old, has been severely criticized by members of the community. It is the duty of a research to assess the contemporary role of that notion in education, defining its strengths and weaknesses.
\end{abstract}

Keywords: good practices; project; ICT; excellence; innovation; learning impact

\section{Introduction}

Where does the need of establishing and maintaining a culture of innovation and excellence spring from? Etymology states as 'innovative' any action or energy that can be characterized by a new, radical or groundbreaking perception of reality (Babiniotis, 2002). Focusing on education, innovation covers those actions that incorporate and promote new perceptions in three dimensions: change of values and principles, implementation of new didactic approaches and use of new didactic means (Fullan, 1991). It is obvious that introduction and systematic use of such actions can advance the whole educational system into a rising level and turn the learning process into an active, authentic and effective experience.

Frequently enough, in modern bibliography, one comes across the term 'good practices'. This is a relatively narrower concept, characterizing actions that involve new strategies in teaching and learning, inside the educational system. According to Grouws D. and Cebulla J. (2000), the essence of 'good practices' is to give equal opportunities for learning to all students, to focus on semantics, to engage students in the problem solution, to create opportunities for idea invention and implementation, to create highly collaborative and interactive environment in classroom. As one can clearly observe, the two notions are not very distant from one another. So, in the current work, they will be used equivalently and interchangeably.

During the last two decades, the majority of the European Union countries have introduced, implemented and assessed innovative educational programs in order to restructure formal learning procedures from atomic memorizing to expeditionary - cooperative. Moreover, their desire was to develop a holistic approach to knowledge, by nourishing skills and attitudes of the young students (CIDREE, 1999). The Greek system could not be missing 
from this attempt. Although not defined as a high order priority, innovative programs of the Ministry of Education were a natural consequence of societal needs in order the Greek school to live up to the contemporary pedagogical and cultural demands and also to rapid technological developments (Ministry of Education, 1992).

During the last years, a whole variety of programs has been established around the phrase 'good practices' and has been subsequently particularized. The institutionalization of environmental education, health promotion actions, cultural issues and Panhellenic artistic competitions and career study centers are among the pillars that support good practices inside school today (Ministry of Education, 2014). As horizontal connecting links, in many cases due to financing reasons, the relevant European programs Socrates (and mostly its sibling Comenius) and today its mutation as Erasmus + , have offered strong parallel support (European Commission, 2014). All these actions have accumulated a lot of experience, so today the education system can enter a more mature phase regarding the embedded use of these techniques.

The general legal framework is also important when considering these issues. A few years ago, a new legal framework for research and technological development was voted by the Greek Parliament, after a lot of intense discussions and vivid debate (Government Gazette, 2014). Within this law, there is an important settlement formulated, concerning secondary education level, which states exactly that: "An amendment is made in article 32 of law 3848/2010 adding, after paragraph 8, paragraphs numbered 9 and 10, as follows: No 9. Inside each of secondary education school-unit an Action Plan should be included the by monitoring, support and evaluation of the available novel activities and programs laying in their jurisdiction area. Also the update of interested teachers and school leaders for the potential implementation of research, technological development and innovation is continuous. The online, telephone and network communications within the schools, cooperation with the directors, teachers and groups of students, information about common partnerships with other schools are also important. No 10. Every Secondary Education Authority allocates in the department of School Activities a teacher with special skills in order to: a) become the link with the Scientific Association of the Ministry of Education, establish close cooperation on implementation of EU and national programs, financially support projects b) develop partnerships with public research organizations to better implementation of programs c) ensure the organization of workshops, conferences and training seminars for teachers d) cooperate with schools to make educational visits possible for students in areas of research organizations" (article No 9, paragraph No 3, Government Gazette, 2014).

Having adumbrated such a rather favorable framework, the next step is to gather information about innovative school activities and relevant projects. Our attention was primarily focused on a database maintained by the Greek Ministry of Education that contained a detailed list of school projects having received an award during the years 2011-2013 (Ministry of Education, 2013). That list numbered approximately 300 different items, including an analytical qualitative description for each (containing parameters such as innovation emerging conditions and disseminations, special attributes and impact e.t.c.). The idea behind that reward was to create a countrywide institution of excellence and innovation, which will pave the way for a creative and open to society school system, staffed with highly trained professional tutors.

\section{The School-Unit Cell}

Educational systems, in all countries, are in a state of continuous change. The reason is that conditions in social, economic and technologic environment are constantly altering, creating affecting waves of turbulence (OECD, 2004). Unfortunately, many of them fail on the way. Why is this so? Because, as it is generally admitted, the driven changes are presented as a forced outcome of top-down rather than bottom-up planning, which means that front-line teachers are not implicated or encouraged to participate in policy design at the first place (Osborn \& Brown, 2005). According to this premise, it is wishful to build horizontal lines of coherence inside every unit in order to achieve both decentralization and deconcentration of authorities and power. This triggers a turn to autonomy at micro level.

Many researchers have studied the ways educational units operate as distinct performance cells in the contemporary social environment (Clark, 2009). This mode of operation implies that school units are considered suitable, at one hand for critical assimilation of the centrally designed educational strategies and at the other for the design and modulation of internal policies into local community level. All collective organs, with the precedence of the Board of Teachers, are authorized to take important decisions on a series of issues regarding e.g. school programming, specific operations, pedagogy and didactic ethics, connections with local communities.

Usually, novel tactics come up as 'reform procedures' that answer different, wider social and educational challenges. The basic preconditions for their deployment, inside the school unit level, are: a) clear vision and objectives, b) coherent consultative and supportive mechanism in planning, curricula and professional development and c) 
accumulated experience of the school teacher in decision making and management of change. All these features constitute an explicit favor in the autonomy of the unit, thus becoming a major challenge for system operation (Lange, 1995).

What are the vital issues that are susceptible of that kind of intervention? The answer defines as well the limits of innovation expansion in the field of future competitiveness. The answer could be curriculum, instructionist methods, authority, human and technical resources and time. The particular challenges and needs of a school unit are possible to be codified, in different ways, considering in the meantime a series of other important issues such as low performance, cultural and social synthesis of student population, juvenile delinquency and bulling, relationships with the local community, changes in the system and their reception (Hanushek et. al., 2013).

The position that school occupies today, inside the frame of educational hierarchy, has clearly shaped a mixture of operations and attitudes that define its culture. Such characteristics are a) the private mode of teaching method and tutor isolation inside classroom b) the formal processing of the educational material c) the absence of accountability and transfer of responsibility d) the closed character of the school establishment. In order for the school-unit to engage in a more active role in the formulation of educational policies, it is important to overcome the above characteristics and reshape a new profile based on the principles of cooperation, responsibility and exploitation of all available resources, in the direction of an open, social school. So, it needs to redesign the structures and the culture based upon them (Intzidis et. al., 2008).

Those needs demand a bund of necessary reforms, which could be applied on the basis of both short and long term schedule. That schedule should contain particular processes that redefine targets and prioritize objectives, seek and modulate alternatives and options, write down conditions and requirements, evaluate, choose and document the best proposals, develop action plans. All these require an open, democratic school with cooperation among its stakeholders and broad coalitions in society, with personal and team responsibility, with development of atomic and collective consciousness (Hopkins \& Levin, 2000).

While educating students on research and technological development and innovation, ingenuity is cultivated, along with technological literacy. Simultaneously, students master applied knowledge and develop critical thinking, acquire skills in the areas of technological problem solving, research, information retrieval, the learning process (learning to learn), creativity, communication, effective use of all available information sources (libraries, publications, discussions with experts, internet websites). Students should also develop an understanding about the workplace, organization, products and production processes in the industry, means of financing, productivity, environment problems and benefits arising from the industrial mode of production, having accurate and 'first hand' information and experiences (Robinson, 2011).

\section{Team Dynamics}

The kernel of success is working in an 'organized' way inside the school - unit. This relies in the close cooperation of teachers and students, while forming of groups or teams and is usually called 'team or group dynamics'. Team-dynamics is a system of behaviors occurring within a social establishment and targeting in a specific aim (Maeroff, 1993). Usually the objective is the collective performance to be better than the sum of the individual ones. Studying this organizational structure can be useful in improving decision making process, diffusion of new ideas and overall efficiency and performance.

The Board of school teachers is the upper steering organ inside school unit. It should operate in an atmosphere of concentration, impartiality and collaboration. A culture of social accountability is required, a culture which fosters high levels of responsibility, both individually and as a group. The basic team-dynamic competent skills and qualifications are listed below, organized in three categories:

- high - level: corporate governance, global experience, leadership management, academia.

- middle - level: strategic thinking, ethics, operations, risk management, human resource management, public policy.

- low - level: accountability, ICT tools and artifacts, regulatory affairs, reputational and social issues.

Those skills reinforce independent teachers who are, in parallel to their primary work, engaged in broad oversight of the entire school policy. Culture of collaboration and teamwork yields inevitably to a sense of ownership, or deeply self-involvement; this is a characteristic of how eagerly is anybody seeking to establish connections as a team. To evaluate performance of the Board itself, a detailed qualitative and quantitative feedback should be included, in the 
frame of the annual school self-assessment review. Ministry of Education has suggested (Government Gazette, 2013) a group of metrics that should be gauged within this context, like:

- effectiveness of group teacher work as a Board, inside and outside classroom

- adequacy and effectiveness of our generic school practices

- quality of their interactions with outside stakeholders (like parent unions)

- satisfaction with their involvement in school management and strategy issues

- level of ICT immersion, as a knowledge-intensive organization

Aggregated results are processed and communicated to the full Board, which recommends, suggests and shapes possible future changes. To focus on excellence, as a permanent attitude, one needs to identify specialized staff members. Characteristics of a possible team coordinator, both for morning and afternoon operation, should be sketched as following:

- sufficient familiarity and knowledge of modern educational theories and their respective methodologies and techniques in flexible (remote) education.

- sufficient familiarity and knowledge of educational theories, methodologies and adult education techniques, focusing on shape motivation and coordination learning systems, in the frame of professional development needs.

- teamwork coordination and cooperation skills of secondary education teachers, counselors and supporting staff.

- capacity building among secondary education teachers on matters related to their everyday work.

- educational planning and management activities (within classroom level), with proficient educators.

- sufficient familiarity with ICT tools, for teaching and instructionist purposes.

- formal qualifications (considered in selection process): degree in Educational Sciences, Educational Technology, Management Education, Training Education-Certification, Planning and Assessment.

- proven experience in using digital learning support systems (e.g. Moodle, WebCT) as certified trainer.

An ad-hoc leadership team should be established within this concept. The authority of professionalism, common decisions and the usefulness of relationships make up the basis for this team. It should be clear, though, that best practices stem up from schools that comply with that specific kind of practice. Here is a short list of common leadership team attributes (Marzano, et. al., 2005):

- formulating and preserving the vision. This distinguishes the manager (according to the weberian logic) from the true leader.

- developing abundant relevant competencies-strategies.

- validating - judging - assessing.

- mentoring.

Internal assessment and evaluation reviews prove that, wherever 'good practices' were applied, they encouraged a different approach to knowledge by empowering tutors and students to create new learning interfaces (Chickering \& Ehrmann, 1996). Specifically, good practices establish new communication channel in classroom, develop reciprocity and cooperation among students, use active learning techniques, respect diverse talents and emphasize on tailor-made didactics!

\section{Research Framework}

The main objective of this work is the study of a collection of awarded 'good practices', developed inside schools during the last years. The gathering, filtering and querying of those data could reveal the basic characteristics of innovation, its common attributes and differences. This action seeks to pave the way to schools fostering continuous improvement, change, diversity and also support teachers' professional development. The current study deals with a repository of 'good practices', that have been posted on the website "Excellence and Innovation" (Greek Ministry of Education, 2011).

The ability of participation does not exclude any teacher as person or team, who wishes to take place. The content of projects submitted may relate to: a) teaching the courses offered in all types of schools, based on the given 
curriculum by the Ministry b) the application of the various forms of school activities (environmental, health, cultural, career education, european mobility programs) c) the processing \& implementation of proposals for effective cooperation of the educational community (director - teachers - students - parents - school counselors school board-entities outside school) in order to enhance the operation of the school (e.g. reduced energy footprint, school opened to the local community, sustainable school) as well as the professional development of in-service teachers and d) actions that promote inclusive education and school for all.

In order to evaluate and rank each of the submitted projects, the evaluation committee has developed 17 different metrics based on 5 core sections (or axes). Each metric is actually a question that measures 1-10 or more frequently 1-5 points. The whole sum is 100 . The five axes are: innovation added value, learning outcome, pedagogic value, applicability and content. The detailed evaluation sheet can be seen in Appendix I. Successful practitioners also answered a detailed questionnaire asking information about how their idea came up, what were the difficulties for its implementation, how the specific innovation could be expanded - disseminated and finally what changes could incur. That sample is presented in Appendix II.

Qualitative data were processed using nVivo QSR software package, while SPSS was used for measurable inferences. All submitted works, which met the eligibility criteria, are assessed against different categories like:

- Innovation: the novelty of the solution, the degree to which the gp (abbr. for 'good practice') shows a leap of creativity in practice (which may include intelligent adaptation, update and extension of past practices or actions), and demonstrates something different that goes beyond what currently exists.

- Impact/results: the realization of planned objectives and activities; the illustration of proven evidence of benefits, visible impact and tangible results (which may be based on objectively high levels of achievement).

- Relevance of actions taken: the particular gp needs and constraints of the context, the target groups and final beneficiaries (students), and how the actions address their real needs.

- Transferability and learning capacity: gp has potential value and lessons to be learnt for other entities because it provides the potential for successful replication in other contexts (e.g. different subjects of curriculum); it stimulates a learning, innovation and self-improvement culture within the entity.

- Sustainability: gp shows or describes elements which allow it to be sustained beyond an initial period of the realization of its objectives and of its activities.

- Stakeholder involvement: the gp shows evidence of stakeholder involvement, e.g. evidence of public and civil society cooperation and/or response to consultation, evidence of political support; in particular, evidence of intelligent engagement with stakeholders which can influence the design and production of services, smart partnership and governance models.

- Social inclusion: gp provides evidence of consideration and application of diversity issues, including, but not restricted to, consideration of gender, age, disability students and geographical location.

Sufficient detail must also be provided for projects to demonstrate the quality of the achievements in general. The assessment is carried out in an independent and impartial multi-step evaluation process.

\section{Results}

Analogous to the criteria mentioned above and the idiosyncratic characteristics of every attempt, some concrete attributes for further categorization are derived, based on school type (private or public sector), school level (primary, secondary and gradations inside), geographic distribution (as they cover the whole country), cognitive (or specialization) area and spanned through the last three years. It is no surprise that many of the submitted projects were based on more or less ICT tools, or consider ICT as an integral part. The innate nature of ICT artifacts favors the creation of large-scale practices and the momentum of such ones as levers (Ellis \& Loveless, 2013).

As long as processing of results is concerned, firstly the quantitative outcomes of the survey are analyzed in order to produce meaningful interpretations. There were 328 cases of 'good practices' encountered, concerning all levels (primary and secondary) and all years (2011-2013). Data concerning primary education were left out, because at this level there is no strict implementation of the syllabus, so innovation ideas have not such a strong impact on formal school operations. Finally, there were in total 184 records in the database, 67 from year 2011, 61 from year 2012 and 56 from 2013.

Trying to filter these projects with the according discipline (or school subject), one sees that there are in english 6, in 
health education 4, in french 9, in german 5, in special education 1 (most of them were reported in the primary level), in theater 2 , in theology 11 , in artistics 15 , in sociology 1 , in math 5 , in music 3 , in house economy 6 , in economics 12 , in environmental issues 14 , in informatics 11 , in culture 4 , in mechanics 8 , in literature 51 , in physical education 1 and physics-chemistry-biology 15.

Regarding types of schools, there were 18 private schools among the participants (mostly from Athens and Thessaloniki). Also, there were 20 pilot - experimental ones. Additionally, there were 16 special education schools. In general, the sample divided into 107 lower-level secondary education schools (gymnasia) and 77 upper-level school (lycea).

Considering geographical distribution, one notices that the majority of awarded school are located in urban areas. An amount of 50 are located in Athens and Attica, 29 come from Thessaloniki, 18 from Peloponnesus, 19 from Thessaly and analogically from other areas, as well as islands (exactly 12). The participating teachers were in total 152 men and 291 women. Time of implementation was reported 54\% inside the school schedule and $46 \%$ in the free time of teachers and students.

Looking on some qualitative results, one is interested in whether there is a change of attitude of students and parents, after the implementation of 'good practices'. The answers gathered towards this are codified in the following matrix:

Table 1. Attitude Change

\begin{tabular}{lccc}
\hline Target group: attitude change & Students (gymnasium) & Students (lyceum) & Parents \\
\hline Database & 412 & 357 & 691 \\
Enough/ too much & $61 \%$ & $51 \%$ & $65 \%$ \\
A little/ no change & $27 \%$ & $26 \%$ & $34 \%$ \\
Do not know & $12 \%$ & $23 \%$ & $3 \%$ \\
Total & $100 \%$ & $100 \%$ & $100 \%$ \\
\hline
\end{tabular}

Another critical factor is the quality of the programs. Since all of them are awarded, the intention drew on two relevant issues, regarding the exploitation of 'good practices': a) the utilization of the demonstrated innovative ideas and b) their application in everyday practice. So, the following information came up:

Table 2. Rate of Dissemination

\begin{tabular}{lcc}
\hline Project ideas dissemination & Exploitation & Successful Application \\
\hline Database & 184 & 259 \\
Very much & $2 \%$ & $7 \%$ \\
Enough & $25 \%$ & $57 \%$ \\
A little & $64 \%$ & $31 \%$ \\
Not at all & $6 \%$ & $2 \%$ \\
Do not know & $3 \%$ & $3 \%$ \\
Total & $100 \%$ & $100 \%$ \\
\hline
\end{tabular}

What about factors that hamper the successful implementation of innovations? Our database responded with the following clues:

Table 3. Impeding Factors

\begin{tabular}{lcc}
\hline Target group: Inhibiting factors & Principals & Teachers \\
\hline Database & 184 & 259 \\
Inflexible curriculum & $44 \%$ & $47 \%$ \\
Implementation outside schedule & $30 \%$ & $35 \%$ \\
Incomplete training & $53 \%$ & $47 \%$ \\
Lack of interest & $38 \%$ & $21 \%$ \\
Lack of information & $33 \%$ & $39 \%$ \\
Lack of infrastructure & $49 \%$ & $57 \%$ \\
Lack of financing & $57 \%$ & $52 \%$ \\
Do not know & $4 \%$ & $3 \%$ \\
\hline
\end{tabular}


Another critical issue focuses on the impact of good practices in the outcome of the school system, as a whole. Here, the following answers were gathered:

Table 4. Outcome

\begin{tabular}{lcc}
\hline Target group: Impact factor & Principals & Teachers \\
\hline Database & 184 & 259 \\
Very much & $47 \%$ & $31 \%$ \\
Enough & $43 \%$ & $51 \%$ \\
A little & $6 \%$ & $15 \%$ \\
Not at all & $2 \%$ & $3 \%$ \\
Do not know & $0 \%$ & $0 \%$ \\
Total & $100 \%$ & $100 \%$ \\
\hline
\end{tabular}

Codifying answers in question No7 (Appendix II), gives the researcher a clear intendancy of good practices' dynamics. There are four distinct areas defining project's innovative nature: characteristics, teaching impact, pedagogic value and facilitations. From the responses, survey processed outcomes show that most practitioners consider the basic characteristic is the redesign of an existing method, teaching impact is at most the increase of student participation, pedagogic value is deemed to covering students' needs and almost equally to increase learning capacity and finally positive climate and collaboration are considered to be the most important facilitations an innovative idea can achieve.

Table 5. Dynamics

\begin{tabular}{|c|c|c|c|c|c|c|c|}
\hline \multicolumn{2}{|c|}{$\begin{array}{l}\text { Project's innovative } \\
\text { character }(7.1)\end{array}$} & \multicolumn{2}{|c|}{$\begin{array}{l}\text { Project's impact on } \\
\text { teaching }(7.2)\end{array}$} & \multicolumn{2}{|c|}{$\begin{array}{c}\text { Project's pedagogic value } \\
\text { (7.3) }\end{array}$} & \multicolumn{2}{|c|}{$\begin{array}{c}\text { Project's facilitations } \\
\text { (7.4) }\end{array}$} \\
\hline $\begin{array}{l}\text { New theoretical } \\
\text { approach }\end{array}$ & $17 \%$ & $\begin{array}{l}\text { Successful learning } \\
\text { results }\end{array}$ & $29 \%$ & $\begin{array}{l}\text { Contribution to student } \\
\text { development }\end{array}$ & $28 \%$ & Ease of application & $9 \%$ \\
\hline $\begin{array}{l}\text { New practical } \\
\text { technique }\end{array}$ & $24 \%$ & $\begin{array}{l}\text { Increase student } \\
\text { participation }\end{array}$ & $43 \%$ & Trigger performance & $6 \%$ & $\begin{array}{l}\text { Create positive } \\
\text { climate }\end{array}$ & $34 \%$ \\
\hline $\begin{array}{l}\text { Redesign of an } \\
\text { existing method }\end{array}$ & $49 \%$ & $\begin{array}{l}\text { Adaptation of } \\
\text { material to local } \\
\text { circumstances }\end{array}$ & $28 \%$ & Address students' needs & $22 \%$ & $\begin{array}{l}\text { Enhance cooperation } \\
\text { and collaboration }\end{array}$ & $41 \%$ \\
\hline \multirow[t]{2}{*}{ Social inclusion } & $10 \%$ & & & Deepen subject area & $17 \%$ & Sustainability & $10 \%$ \\
\hline & & & & Learning capacity & $27 \%$ & $\begin{array}{l}\text { Stakeholder } \\
\text { involvement }\end{array}$ & $6 \%$ \\
\hline
\end{tabular}

\section{Pilot - Experimental Institutions}

In another, complementary, area of interest, one seeks for excellence in the secondary education level, where there is the well-known example of pilot - experimental schools. These types of schools were advertises as 'locomotives of excellences', within the law that inaugurated them along with another important institution, experimental schools (Ministry of Education, 2011).

It is suggested that under the reforms implemented to improve Greek educational system, Pilot Schools stand in the cutting edge of change and are sought to be tuned towards excellence. So, the admission process of students in those schools needs to be filtered by exams, an opinion that has raised a lot of controversies lately. Also, staff appointment has to conform to high quality standards, another thorny subject for the teachers' Union.

These Schools are governed by a steering committee, which has access to the leadership team of the Ministry and all relevant top - level institutions. Design of a network of 70 such schools (half in primary and half in secondary education level), hosting 15.000 students, seems to be a realistic plan for the next years, according to the Minister. Those students will be given the opportunity to pursue excellence, contribute to the country welfare as prospective 
scientists and provide for themselves prosperity and satisfaction.

On the other hand, there is a lot of severe criticism asserted on this type of schools. Many pedagogists consider them as 'products' of the times of crisis, when public spending for broad social infrastructures (like education) has been drastically cut. Those schools say their opponents, are only euphemistically 'pilot', or 'experimental' or anything else, usually incompatible with social prosperity and humanitarian values. They claim that student categorization reproduces inequalities and broadens the gap between those who have and those who don't. So, everything is measured by its economic impact and every idea is sacrificed in the altar of fiscal growth.

\section{Discussion}

It is a common belief that good practices can contribute to change in classroom and also help in establishing a new learning contract among teachers and students. Empirical data from the survey validate this hypothesis. Specifically, as long as the pervasiveness of the innovative programs is concerned, two distinct tutor categories were distinguished: the first one includes those teachers who are not in favor of running these programs. They consider that good practices and innovations are useful enough to act as ancillary services to the learning process. This argument is usually supported by professionals who have years of in-service, especially in secondary high-level. The second category contains those who believe that innovative programs play not just supportive but integrally important role in the system. This perception usually comes from tutors that are young, ambitious and sensitive, and seek new methods of teaching and learning behind the given formalities (Spiropoulou et. al, 2010).

Wherever good practices have been implemented, they always leave the best impressions behind, especially in the student target group. This fact is being highlighted by almost all stakeholders. At the same time, it is the believe among principals that these programs are being carried out neglecting the normal schedule, thus consuming precious teaching hours at the exchange of excessive exposure of school in the local community. This, sometimes, creates a lot of murmur from parents and teachers of higher classes, particularly.

The truth lies somewhere in between. School undoubtedly has a difficult and diverse role to accomplish: from one side it must convey all the chunks of formal knowledge as officially directed by the Ministry of Education and moreover assess the degree of absorption of each student separately, and on the other side it must be open to the society, cultivate ethos and values and mold strong, responsible characters for the next generation to come. It is actually, at the same time, an incubatory of the youth and a micrograph of the contemporary society. Thus, a lot of work is still needed in order to succeed in both these challenges!

\section{References}

Babiniotis, G. (2002). Leksiko tis Neas Ellinikis glossas [Dictionary of Modern Greek language]. Athens: Centre of Lexicography.

Chickering, A. W., \& Ehrmann, S. C. (1996). Implementing the seven principles: Technology as lever. AAHE bulletin, 49, 3-6.

CIDREE (1999). Across the great Divides: Interdisciplinary teaching and learning in secondary schools. Athens: Hellenic Educational Institute.

Clark, D. (2009). The performance and competitive effects of school autonomy. Journal of Political Economy, 117(4), 745-783. https://doi.org/10.1086/605604

Ellis, V., \& Loveless, A. (Eds.). (2013). ICT, pedagogy and the curriculum: Subject to change. Routledge.

European Commission (2014). Erasmus + : EU program for education, training, youth and sport. Retrieved from http://ec.europa.eu/programmes/erasmus-plus/index_en.htm. Last accessed 25/2/2015.

Fullan, M. (1991). The New Meaning of Educational Change. London: Cassell.

Government Gazette (2013). Evaluation of teachers in primary and secondary level education. PD 152/5-11-2013, Athens.

Government Gazette (2014). Research, Technological Development and Innovation. Law 4310/2014, FEK 258. Athens.

Grouws D., \& Cebulla K. J. (2000). Improving Student Achievement in Mathematics: Part 1: Research Findings», Published by ERIC.

Hanushek, E. A., Link, S., \& Woessmann, L. (2013). Does school autonomy make sense everywhere? Panel estimates 
from PISA. Journal of Development Economics, 104, 212-232. https://doi.org/10.1016/j.jdeveco.2012.08.002

Hopkins, D., \& Levin, B. (2000). Governmental Policy and School Development. School Leadership and Management, 20(1), 15-30. https://doi.org/10.1080/13632430068851

Intzidis, B.I, Kavouras, P., Karantzola, E., Koleza, E., Koyzelis, G., Repousi, M., \& Mayrogiorgos, G. (2008). Educational Design and Innovations. Retrieved 25/1/2009 from http://schoolnet.protovoulia.org/practice

Kerzner, H. R. (2013). Project management metrics, KPIs, and dashboards: a guide to measuring and monitoring project performance. John Wiley \& Sons. https://doi.org/10.1002/9781118826751

Lange, H. (1995). School Autonomy. Problems of Decision-Making from a Politico-administrative Point of View. Zeitschrift fur Padagogik, 41(1), 21-37.

Maeroff, G. I. (1993). Team building for school change: Equipping teachers for new roles. Teachers College Press, 1234 Amsterdam Avenue, New York, NY 10027.

Marzano, R. J., Waters, T., \& McNulty, B. A. (2005). School leadership that works: From research to results. Association for Supervision and Curriculum Development. 1703 North Beauregard Street, Alexandria, VA 22311-1714.

Ministry of Education (1992). School Activities. Document number G2/4867/28-8-1992, FEK 629B, by the Greek Ministry of Education. Athens.

Ministry of Education (2011). Operational Framework of Pilot - Experimental Schools. Law number 3966/2011, FEK $118 / 2011$, by the Greek Ministry of Education. Athens.

Ministry of Education (2013). Institution of Excellence, Operational Program: Education and LLL. Retrieved 17/1/2014 from http://excellence.sch.gr/index.php Institute of Computer Technology and Publications, Diofantos.

Ministry of Education (2014). Design and Implementation of school activity Programs. Document number 167127/G7/15-10-2014, by the Greek Ministry of Education. Athens.

OECD (2004). Innovation in the Knowledge Economy - Implications for Education and Learning. OECD Publication Services.

Osborne, S., \& Brown, K. (2005), Managing Change and Innovation in PSO. Routledge. UK.

Robinson, K. (2011). Out of our Minds, Learning to be Creative. Capstone Publishing Ltd, UK, (updated).

Silver, C., \& Lewins, A. (2014) Using Software in Qualitative Research - A Step-by-step Guide. Second Edition, London: Sage. https://doi.org/10.4135/9781473906907

Spiropouou, D., Anastasaki, A., Deligianni, D., Koutra X., \& Bouras S. (2010). Innovative programs in education. Cited at http://repository.edulll.gr. Last accessed at 17/1//2014. Athens 


\section{APPENDIX I: SAMPLE GRADING SHEET}

Following is sample sheet that was used from our point of view in order to make a first evaluation table of the award innovative practices:

\begin{tabular}{|c|c|c|}
\hline \multicolumn{3}{|c|}{ Section 1: innovation, added value } \\
\hline A1 & $\begin{array}{l}\text { Does this practice produce an innovative, theoretically justified, approach to the } \\
\text { educational procedure? }\end{array}$ & $1-10$ \\
\hline A2 & $\begin{array}{l}\text { With this work, is a new innovative practice or an educational approach } \\
\text { introduced for the very first time? }\end{array}$ & $1-5$ \\
\hline A3 & $\begin{array}{l}\text { With this work is it the rehabilitation or the restructuring of the established } \\
\text { didactic approach asserted themselves? }\end{array}$ & $1-5$ \\
\hline A4 & Does this work create added value to the educational process? & $1-5$ \\
\hline \multicolumn{3}{|c|}{ Section 2: Learning Outcome } \\
\hline B1 & $\begin{array}{l}\text { Did the project implementation in class show that there are satisfactory learning } \\
\text { outcomes? }\end{array}$ & $1-5$ \\
\hline B2 & $\begin{array}{l}\text { Does this project help students comprehend and immerse into the negotiable } \\
\text { knowledge area? }\end{array}$ & $1-5$ \\
\hline B3 & Does the project help students learn "how to learn"? & $1-5$ \\
\hline B4 & Does the project promotes active participation of the trainees? & $1-5$ \\
\hline \multicolumn{3}{|c|}{ Section 3: pedagogic value, adaptation } \\
\hline $\mathrm{C} 1$ & $\begin{array}{l}\text { Does this work contribute to the personal, social and cultural development of } \\
\text { students? }\end{array}$ & $1-10$ \\
\hline $\mathrm{C} 2$ & Is this work adapted to local conditions and needs? & $1-5$ \\
\hline $\mathrm{C} 3$ & $\begin{array}{l}\text { Does this work create motives for higher expectations and reinforces students' } \\
\text { interest? }\end{array}$ & $1-5$ \\
\hline $\mathrm{C} 4$ & Is this work focused to student's needs? & $1-5$ \\
\hline \multicolumn{3}{|c|}{ Section 4: applicability, contribution } \\
\hline D1 & Is this work easily applied to other school of the same educational level? & $1-5$ \\
\hline $\mathrm{D} 2$ & Does the work help to strength relations between students? & $1-5$ \\
\hline D3 & Does this work help to develop cooperation between teachers of the school unit? & $1-5$ \\
\hline D4 & $\begin{array}{l}\text { Does this work help formulate a positive climate between the school and the } \\
\text { parents? }\end{array}$ & $1-5$ \\
\hline D5 & $\begin{array}{l}\text { Does the work help change of attitudes towards handicapped students, promotes } \\
\text { co-education and a school open to anyone? }\end{array}$ & $1-5$ \\
\hline \multicolumn{3}{|c|}{ Section 5: Proposal content } \\
\hline E1 & Is there congruity between filling bureaucracy forms and content of proposal? & $1-10$ \\
\hline
\end{tabular}




\section{APPENDIX II: QUESTIONNAIRE}

Form of successful project documentation by its writers:

1. Write a summary of your innovation action (description)

2. Describe how the idea for this action came up (start-up)

3. Describe analytically the innovation action as well as the implementation process to the school curriculum or community (implementation)

4. Describe the ways by which the application should be extended to other disciplines in school unit (expansion - dissemination)

5. Describe the conditions under which it would better be developed at school (improvement)

6. Describe the conclusions/ outcomes you draw out of this action (evaluation)

7. Please justify (documentation) in terms of:

7.1 the innovation character of the submitted project in relation to the:

a) production of a new approach in the educational process that is based on solid theoretical documentation

b) introduction for the first time in school of an established practice of pedagogical approach

c) redesign of an established instructionist approach

d) need for social inclusion of specific groups

7.2 the project contribution in improving the teaching act such as:

a) the successful learning results

b) the promotion of trainee participation

c) the preparation of learning materials adapted to the local circumstances and the students' needs

7.3 the pedagogic value of the project as the following:

a) contribution to personal, social and cultural development of students

b) incentives to achieve higher expectations

c) focus on students' needs

d) better understanding/ deepening in the subject area

e) facilitating the process of "learning to learn"

7.4 contribution to the overall function inside the classroom:

a) ease of application

b) creating a positive climate in school community relations and parent relationships

c) cooperation among teachers

d) sustainability

e) involvement of stakeholders (e.g. parents, municipal services) 